\title{
Assessing ESL Teachers' Knowledge and Readiness in Integrating 4IR into Teaching Practices: A Concept Paper
}

\author{
Nur Maechea Avelino' ${ }^{1}$, Hanita Hanim Ismail² \\ ${ }^{1}$ SJKC Ladang Grisek, Pasir Gudang, Malaysia \\ ${ }^{2}$ Faculty of Education, Universiti Kebangsaan Malaysia, Bangi, Malaysia \\ Email: hanitaismail@ukm.edu.my
}

How to cite this paper: Avelino, N. M., \& Ismail, H. H. (2021). Assessing ESL Teachers' Knowledge and Readiness in Integrating 4IR into Teaching Practices: A Concept Paper. Creative Education, 12, 2038-2055. https://doi.org/10.4236/ce.2021.129156

Received: July 21, 2021

Accepted: September 5, 2021

Published: September 8, 2021

Copyright $\odot 2021$ by author(s) and Scientific Research Publishing Inc. This work is licensed under the Creative Commons Attribution International License (CC BY 4.0).

http://creativecommons.org/licenses/by/4.0/

\begin{abstract}
English as Second Language (ESL) teachers' ability to integrate technologies has an insightful impact on students' language performance as well as their educational development. Thus, inquiring teachers' level of knowledge and readiness in their practice of integrating Industrial Revolution 4.0 (4IR) into their teaching practices is necessary. Besides reviewing past literature on teachers' level of knowledge in 4IR and factors that affect teachers' level of readiness, this paper provided a conceptual framework that can be useful to measure teachers' level of knowledge and readiness in integrating 4IR into their teaching. The determinants highlighted are analysed mainly using theoretical framework based on TAM3 model. The research questions formed are derived from two variables-level of knowledge and level of readiness among ESL primary school teachers. It is hoped that this study could highlight the effectiveness of the framework in analysing ESL primary teachers' level of knowledge and readiness in integrating 4IR in their teaching practices.
\end{abstract}

\section{Keywords}

ESL Primary Schools, Teachers' Level of Knowledge on 4IR, Teachers' Readiness to Integrate 4IR, 4IR, TAM3

\section{Introduction}

Education is one of the thrusts that help enhance the present development in Malaysia. Thus, teachers play vital role in moulding the young generation into citizens who can contribute to the country (Ong et al., 2019), which is supported by Sulaiman, Hamzah, \& Rahim (2017), claiming that teachers are role models 
in nurturing human resources that help boost national economy. A constructive ESL primary school teacher is able to understand skills and knowledge clearly before imparting them to their pupils. This shows that teachers, especially ESL teachers, are responsible to impart social and intellectual development to the young generation since teachers are one of the main catalysts to determine their pupils' future prospects. In order to be constructive while maintaining good role model, ESL teachers should be equipped with pedagogical and methodological skills that are aligned with the advancement of technologies nowadays.

The present advancement of technologies originally started from Industrial Revolution 1.0 (IR 1.0). Schwab (2016) explained how industrial revolutions changed over time where during Industrial Revolution 1.0, mechanize production used water and steam while Industrial Revolution 2.0 witnessed mass productions which were created by using electric power. During Industrial Revolution 3.0, automate production was created through electronic and information technology, followed by 4IR that emerged due to advancement of new technologies that contribute to uncertain boundary between the physical, digital and biological worlds. The precedence of 4IR advancement is caused by inception of the Internet of Things (IoT), bio and nanotechnology, 3-D printing, material science, to mention some (Diwan, as cited in Anaelka, 2018).

The advancement of technologies in the present world is undeniably omnipresent in nature since it has become a part of everyone's life. Himmelsbach (as cited in Van et al., 2021) stated that Internet allows us to access and gather information 24-hours a day, which is supported by Ahmadi (2018), stating that technology can be a tool to facilitate pupils' learning process as it makes them learn smoothly and effectively. Thus, it is not surprising to see how 4IR has caused a gradual shift from traditional teaching to digital teaching. Many teaching theories and research findings indicated an enhanced teaching quality when it is facilitated by digital teaching (Al-Maroof et al., 2021; Van et al., 2021; Lawrence et al., 2019; Hashim et al., 2019; Mofareh, 2019; Ahmadi, 2018; Xu et al., 2018; Yunus, 2018), which also affects learning outcomes (Quarles et al., 2018). Fisk (as cited in Anaelka, 2018) also stated that with the new vision of learning, pupils are not only promoted as learners who learn necessary skills and knowledge, but they are also responsible to identify sources that enable their learning these skills and knowledge. As such, ESL teachers are responsible to facilitate their pupils by providing them with the right environment or facilities that enable their learning while monitoring performance through data-based customization. Teachers find data-based customization much easier and effective as teachers can monitor their pupils' language learning process as learning can happen anytime and anywhere through e-learning tools (Anaelka, 2018) e.g. Google Classroom, where teachers can track their pupils' progress in completing tasks and give suitable grade or marks based on their performance. This shows that 4IR has greater impact in teachers' teaching practice, especially in ESL classrooms since English is more prominently important in local or global communication. 


\section{The Research Question}

Consequently, this paper asked two research questions:

1) To what extent, does ESL primary teachers' level of knowledge of 4IR help them to integrate $4 \mathrm{IR}$ in their teaching practice?

2) How does ESL primary teachers' level of readiness affect their integration of 4IR in their teaching practice?

Answering this question will be based on extended review and literature analysis. 4IR is a new era of technology that helps enhance people and technology relationship where new job opportunities are created along the efforts to boost Malaysia's economy. Teachers as one of the main pillars of young generation's future should be aware and equip themselves with 4IR elements in their teaching practices. Therefore, this conceptual paper is significant to stakeholders (e.g. education policymakers, teachers-educators and primary school management authorities) since this research explored the level of knowledge and readiness that influence the integration of technologies in a 4IR context as well as support decision-making in designing future research that able to enhance the integration of 4IR in teaching practices. Future research may be able to help them to explore factors that affect teachers to integrate technology in their teaching practices as well as methods to face challenges in integrating 4IR elements in their teaching practices.

The conceptual framework is derived from variables; perceived ease of use and perceived usefulness to assess ESL teachers' level of knowledge and readiness in integrating 4IR in their teaching practices. This framework would assist the authors to interpret the conceptual scope, systemize relation among concepts and identify gaps in the literature. Recommendation for the future research will be proffered after the authors identified variables based on the review of the related literature.

\section{Literature Review}

\subsection{The Conceptual Analysis}

Technology Acceptance Model 3 (TAM3) is a combination of Technology Acceptance Model 2 (TAM2) (Venkatesh \& Davis, 2000) together with a model for the determinants of perceived ease of use that proposed by Venkatesh (2000). TAM3 model conveys a complete nomological networks of the determinants when users adopt and use information technologies (IT) which includes three theoretical extensions; 1) perceived ease of use and perceived usefulness, 2) computer anxiety and perceived ease of use, and 3) perceived ease of use and behavioural intention where these extensions are beyond TAM2 and the model of the determinants of perceived ease of use (Venkatesh \& Bala, 2008). Thus, in order to investigate ESL teachers' level of knowledge and readiness in integrating 4IR in their teaching practices, the authors proposed to use this model since there are no crossover effects between determinants of perceived usefulness and perceived ease of use when ESL teachers integrate technologies in their teaching 
practices. Despite not having any theoretical nor empirical basis to expect the determinants of perceived usefulness will have impact on perceived ease of use and vice versa, Venkatesh and Bala (2008) believed that either social influence process or cognitive influence process are able to affect stable computer-related characteristics and emotions, which refer to computer self-efficacy, computer playfulness and computer anxiety.

There are two prime factors affecting ESL teachers' behavioural intentions when they use technologies: 1) perceived usefulness and 2) perceive ease of use that (as shown in Figure 1).

These prime factors are variables to determine ESL teachers' level of knowledge and readiness in integrating $4 \mathrm{IR}$ in their teaching practices. However, this is a general TAM3 model that serves as a foundation in this present paper. Venkatesh and Bala (2008) stated that these prime factors have their own attributes that affects the outcomes for each factor. Furthermore, TAM3 suggested experience that acts as a moderator for three relationships in TAM3. These relationships are 1) perceived ease of use and perceived usefulness, 2) computer anxiety and perceived ease of use and lastly, 3) perceived ease of use and behavioural

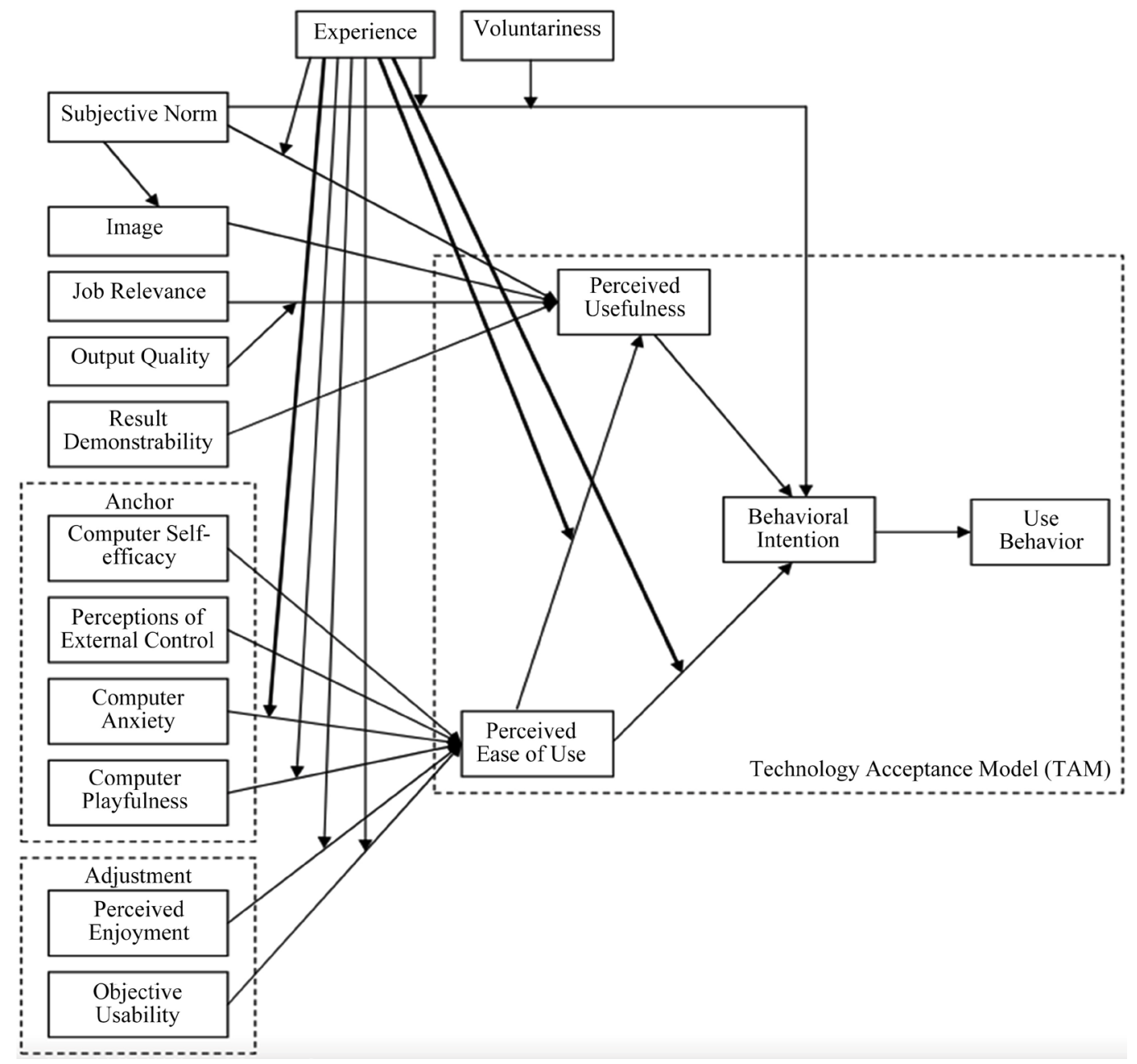

Figure 1. Technology acceptance model 3 (TAM3) (Venkatesh \& Bala, 2008). 
intention when ESL teachers integrate 4IR into their teaching practices. Since TAM3 is generally applicable across various research regarding technologies, there is a need for the writing of this conceptual paper in order to provide another theoretical framework which focuses solely on the level of knowledge and readiness of ESL teachers in integrating 4IR into their teaching practices. Therefore, the authors simplified the theoretical framework in this paper (as seen in Figure 2).

Figure 2 serves as a basic theoretical framework that will be used to investigate the level of knowledge and readiness of ESL teachers in integrating 4IR in their teaching practices. Based on Figure 2, there is strong correlation between experience and three relationships that affect behavioural intention that will be used to evaluate ESL teachers' level of readiness of 4IR. We also can see that the level of knowledge is a major determinant of perceived ease of use which will lead to investigate ESL teachers' level of readiness in integrating 4IR in their teaching practices.

Therefore, in order to investigate the level of knowledge and readiness in integrating 4IR in their teaching practices among ESL primary school teachers, authors proposed to use adaption of TAM3 model as guideline to obtain data needed.

\subsection{IR and Malaysia Education}

Industrial Revolution first emerged in the last 200 years with the presence of the Industrial Revolution 1.0 (IR 1.0) (Maria, Faaizah, \& Pee, 2018), which caused people to become more competitive as well as improved their life in general (Maziahtusima et al., 2018). IR 1.0 evolved from using steam and charcoal to Industrial Revolution 2.0 (IR 2.0) where they used electric and concept of assembly line in order to produce massive production of cars in America. What followed was called the Industrial Revolution 3.0 (IR 3.0) which introduced the revolution of information technologies and automation, where later emerged 4IR as a result of Cyber Physical Systems that was introduced by Germany in the industrial sector in 2013 (Anon, 2020). In lieu of that, people generally use

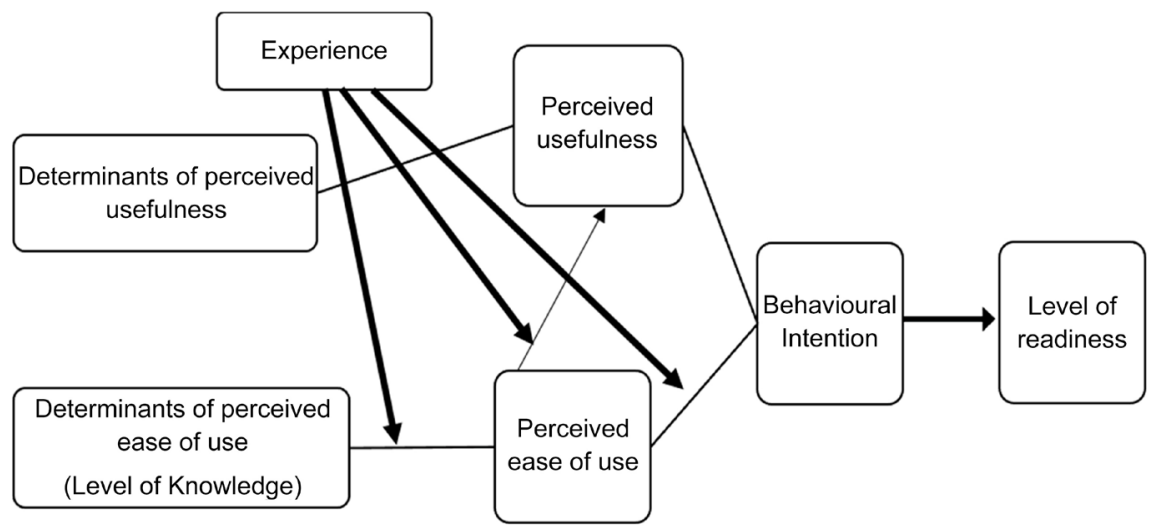

Figure 2. An adaption of theoretical framework of TAM3 (Venkatesh \& Bala, 2008). 
information technologies and the Internet. Anon (2020) also claimed that 4IR is a transformation of information being delivered and received as these 4IR elements can connect to big data, people, other sources, services as well as the IoT, which allows collaboration and innovation within the ecosystem to become easier and accessible.

As technological developments advance rapidly, causing many sectors to change, especially the education sector, there is a need for the modification of Malaysian education to suit the demands of 4IR (Lawrence, Lim \& Haslinda, 2019). While it is predicted that many present jobs will diminish in the future, there will also be numerous new job prospects which are influenced by 4IR. Anaelka (2018) reiterated this, claiming that $4 \mathrm{IR}$ affect the education when human and technologies are in sync, causing the creating of new job opportunities that are suitable with 4IR demands.

In the Malaysian context, 4IR is emphasized in tertiary education as compared to primary or secondary education where the Ministry of Higher Education (2018) proposed a framework for Malaysian Higher Education 4.0 which includes four main elements in order to address the challenges of 4IR in higher education, namely 1) Future Ready Curriculum, 2) Agile Governance, 3) Research and Innovation and 4) Talent Planning. However, as the demands of 4IR continuously increase, the Malaysian education should focus and implement 4IR elements from primary level, especially in the teaching of English. This is to ensure that teachers are able to help pupils to be equipped with future proof skills that can harness their humanistic, technological and data analytic competencies at embracing 4 IR.

In conclusion, advancement of technologies nowadays has caused a big change in various sectors where each sector, especially education, to change and revolutionize in order to adapt with the 4IR demands (Anon, 2020). Therefore, ESL primary teachers should be aware and know how to integrate 4IR elements into their teaching practices so that they are able to help their pupils to overcome challenges that arise from $4 \mathrm{IR}$.

\section{Elements in 4IR}

Ministry of Higher Education acknowledges that 4IR leverages on advancements in digital technology which make them realize that there is a need to transform higher education curriculum in order to stay pertinent and competitive in the higher education sector worldwide. Thus, the Ministry of Higher Education (2018) thinks it is necessary to transform the education and industry by enhancing, reskilling and upscaling talents that can help synergise the core existence of humanistic values and intelligent machines by implementing Higher Education Framework 4.0 (MyHE 4.0). MyHE 4.0 specifies in great length about 4IR with regards to its background information, impacts, challenges, and future alternatives to ensure that educators in the higher education can produce ethically and morally upright citizens. There are nine elements of 4IR as listed in MyHE 4.0, which are aligned with those proposed by Erboz (2017), which are 1) autono- 
mous robot, 2) simulation, 3) cloud computing, 4) system integration, 5) IoT, 6) cyber security, 7) 3D printing, 8) Augmented Reality (AR), 9) Big Data and Analytics.

Manufacturing industries use autonomous robots to solve complex tasks that cannot be easily solved by human beings. 4IR accelerates the usage of industrial robots in factories since robots can be used in activities e.g. the production line, logistics and distribution. More importantly, it can be controlled by man (Erboz, 2017). Bahrin et al. (2016) claimed that robots have the ability to learn from human beings who then become their colleagues, besides functioning as a platform for checking, optimizing and documenting tasks with the help of cloud systems. Besides that, simulation, which is another element in 4IR, is usually integrated into education and consists of digital tools that play a supportive role in production activities that can promote sustainable manufacturing environment since it has the ability of self-configuration (Erboz, 2017). In the education sector, simulation is important because it is not only applicable to all levels and age range but also beneficial to pupils because they can now see complex relationships in a safer environment (Kincaid et al., 2003). Meanwhile, cloud computing leads to many positive impacts in the advancement of technologies, e.g. Google Drive, Windows Azur by Microsoft and lastly, BlueCloud which was introduced by IBM (Haug, Kretschemer, \& Strobel, 2016). Erboz (2017) claimed that Big Data is collected by industrial networks and sent to cloud in order to optimize the system performance as well as to create a framework of smart factory for the coordination system. IoT is also another element in 4IR, which refers to future technological revolution that uses cloud-based system to give solutions for computation or analysis data needed (Erboz, 2017). Another element in 4IR is 3D printing, which is also known as additive manufacturing where it produces customised goods that meet clients' requirements. One example of 3D printing can be seen in aerospace companies, which reduces aircraft weight and raw material usage through the use of 3D printing (Rüßmann et al., 2015). Besides that, AR functions as an interactive technology that enables the virtual world to become part of the reality by connecting between the two (Erboz, 2017). Dunwil (as cited in Nor Azizah et al., 2019) predicted that educational landscape will change due to virtual and augmented realities to became true when AR has facilitated educators at improving their teaching and learning with the integration of virtual reality. The last element in 4IR is cyber security, which has a massive destructive impact to the industry or business if there are harmful intentions, such terrorist attack. Cho and Woo (2017) claimed that the panacea against cyber-attack will be expensive but paying for the consequences of cyber-attack is far more exorbitant.

All these nine elements of 4IR should be familiar among ESL primary teachers in order to allow their integration of 4IR into their teaching practices, even if they do not use all the elements in their practices. Furthermore, pupils among the younger generation basically know technology better than adults since tech- 
nology helps them to learn better and easier. Thus, teachers need to equip themselves with knowledge and skills related to technologies and 4IR that make the teaching of English in the classrooms easier and more effective.

\subsection{ESL Primary Teachers in 4IR Context}

English as a medium is capable of bringing various impacts to the international communication activities. This is reiterated by Grabe and Stroller (as cited in Ahmadi, 2018), claiming that pupils use different skills in learning English language such as reading, writing, listening and speaking. Therefore, it is important for ESL teachers to facilitate their pupils' language learning process with suitable methods and approaches. Ahmadi (2018) also proposed that methods that teachers use to facilitate the process of language learning in their teaching practices as one of the important aspects in a language learning process. The use of technologies has become indispensable in teaching of English language, especially in the wake of unprecedented development across numerous fields and disciplines. In lieu of that, ESL teachers should keep abreast with the global technological revolution, which is also triggered by 4 IR.

ESL primary school teachers can adapt and adopt modern technological tools (e.g. computerization, multi-media devices, mobile phone, audio or visual effect application and social media) in order to optimize English language instruction as well as to equip themselves with methods to communicate with their pupils effectively and amicably. Using modern technology as part of teaching English is not only bounded to the use of modern appliances and devices but also more towards procuring to the introduction of innovative systems and methods that enable the fostering and facilitating of learning process so that learning process can be easier and comprehensive (Mofareh, 2019). Thus, ESL teachers, who use technology, are able to consolidate the integrated view of modern teaching methods or approaches with other components which are beneficial for pupils in order to achieve the required results.

There are numerous studies on using a range of technological approaches and methods in order to investigate how these technological elements affect teachers' role and effects of using technologies in the language learning process (e.g. Van et al., 2021; Oke \& Fernandes, 2020; Rafiq et al., 2020; Lawrence et al., 2019; Mofareh, 2019; Ahmadi, 2018; Maziahtusima et al., 2018; Quarles et al., 2018). There are also various technological approaches and methods that teachers can use to enable pupils' language learning process e.g. cognitive and social approach. While cognitive approach offers a meaningful opportunity which teachers can provide in order to expose pupils to language learning and later make the knowledge as their own meaning, social approach allows teachers to provide pupils to experience meaningful and authentic social interactions in the effort to practise language skills acquired through real-life experiences (Warschauer, as cited in Mofareh, 2019).

The Malaysian Education Blueprint 2013-2025 serves as a guideline that pro- 
vides a plan for a sustainably and durable educational transformation in the Malaysia education system. Accordingly, more schools are inspired to upgrade their school with internet connection, smart white boards, LCDs as well as computer laboratory for their pupils' benefits. ICT tools and equipment are expected to be integrated in their teaching practices to familiarize pupils with technology-based learning. Despite all these, teachers' level of knowledge and readiness in integrating technologies that evolve due to 4IR remain problematic when Ministry of Education attempted to implement the policy and plan in Malaysia Education Blueprint (2013).

\subsubsection{ESL Teachers' Level of Knowledge and Readiness in 4IR}

Many studies from different geographical locations investigated on teachers' understanding, knowledge, readiness and attitude in using technologies in a 4IR context. Oke and Fernandes (2020), for instance, found out that teachers in Africa were able to better understand about $4 \mathrm{IR}$ as they used Unified Theory of Acceptance and Use of Technology (UTAUT) to assess teachers' readiness in integrating 4IR into teaching practices. However, they also felt that the African education is still unable to utilize 4IR fully since they are lacking in basic technologies. Because of that, Oke and Fernandes (2020) proposed that teachers play a vital role in maximizing the potential to utilize or integrate 4IR in their teaching practices since 4 IR has positive and negative effects on the education sector.

Similarly, Kamaruddin and Che (2018) observed that trainee teachers in a Malaysian teacher institutes had an average level of knowledge on 4IR, despite a high indication of soft skills in using 4IR elements. This shows that theses trainee teachers did not fully understand 4IR despite their ability to use it well. Nevertheless, they should be prepared as trainee teachers who will face more advanced technologies in the future. Jones and Pimdee (as cited in Kamaruddin \& Che, 2018) suggested trainee teachers to inculcate a more competitive attitude when dealing challenges in 4IR. After all, teachers, including trainee teachers are expected to be responsible to ensure that their pupils' need and development are fulfilled. Because of that, these educators need to be prepared to integrate technologies in 4IR in their teaching practices.

Countries (e.g. America, United Kingdom, China, and Australia) have integrated curricula with subjects that tackle the needs of 4IR e.g. the introduction of AI, robotics, IoT, and coding (Mpungose, 2020). Consequently, there is a dire need for universities or teacher institutes to develop curricula that are able to help and improve trainee teachers with advanced technological knowledge. Mpungose (2020) concurred with Gleason (2018) and Balkaran (2017), claiming that an amalgamation of the physical, digital and biological spheres of 4IR drives for the creation of a new curriculum to ensure that trainee teachers have advanced technological knowledge. If trainee teachers possess advanced technological knowledge, they will be able to help their pupils to function better in this current digital and advanced technological-driven revolution.

Similarly, there are a series of studies done on investigating teachers' level of 
readiness to integrate 4IR into teaching practices. Romy et al. (2020) observed that while trainee teachers' level of knowledge on 4IR are at average level, their level of readiness to integrate 4IR into their teaching practices is low. They proved that trainee teachers in a Malaysian teacher institute are not prepared to face challenges in integrating 4IR in their teaching practice. Therefore, Romy et al. (2020) suggested for trainee teachers' greater participation in trainings (e.g. workshops) that can stimulate further understanding on 4IR. They also suggested for the provision of more facilities in learning institutions that enables trainee teachers to easily access the Internet in the pursuit of preparing for 4IR readiness.

On the other hand, Subekt et al. (2017) proposed for the use of Science, Technology and Mathematics (STEM) approach to help teachers become prepared in integrating 4IR elements in their teaching practices. They also suggested for more research in helping teachers to become ready at facing challenges that arise from technology revolution and 4IR with using STEM approach since STEM is one of effective approaches that teachers can use, especially science teachers (Subekt et al., 2017). Similarly, Nor Azizah et al. (2019) showed that teachers' level of knowledge, understanding and readiness in dealing with $4 \mathrm{IR}$ is at a moderate level. They also discovered that Malaysian teachers are still premature when it comes to integrate 4IR into teaching practices. Their gender and teaching experience did not affect their level of knowledge, understanding and readiness in integrating 4IR into their teaching practices.

Aprianti and Sahid (2020) indicated a significant relationship between teachers' competence and their learning of 4IR where there are significant impacts from the combination of teachers' competencies and their learning of 4IR. Teachers should enhance their knowledge since they are the ones who will develop their pupils' imagination, creativity, character, teamwork and social empathy (Aprianti \& Sahid, 2020). They proved that teachers' knowledge on 4IR is highly significant with their readiness to integrate 4IR into their teaching practices, which helps teachers cope with challenges in dealing with 4IR.

Moreover, it is proven that 4IR tremendously affect education and economic systems. Past studies conducted to investigate the effects of 4IR in economic and education systems where the result showed that opportunities and prospects that surge were caused by advanced technologies that are driven from 4IR (e.g. Butler-Adam, 2018; Schafer, 2018; Xu et al., 2018; Schwab, 2016). These studies further outlined that trainee teachers need to be equipped with skills and advance technological knowledge, ergo, needing new development in their education module or courses align with 4IR demands. This suggests that technological knowledge on 4IR has become a major knowledge that trainee teachers should master and they should master in delivering the curriculum to their future pupils Trainee teachers should attend more courses or seminars with regards to integrate 4IR elements in their teaching practices as well as opportunities to utilize 4IR during their training practices as teacher trainees. 


\subsubsection{Challenges in Integrating $4 I R$ in ESL Context}

Malaysian classrooms in general shifted from traditional classrooms into those equipped with technologies (e.g. projectors, laptop and wireless internet) (Yunus, 2018). However, conducting these classrooms as part of meeting the demands of 4IR is challenging (e.g. Anaelka, 2018; Lawrence et al., 2019; Oke \& Fernandes, 2020) since teachers or trainee teachers are neither well-equipped with knowledge of 4IR nor competent to integrate 4IR into their teaching practices. One of these challenges is discussed by Pazilah, Hashim and Yunus (2019); the employment of technologies in classrooms restricts pupils' thinking potential since they tend to find answer online, instead of thinking on their own. This is echoed by Shyamlee and Phil (as cited in Pazilah et al., 2019), reiterating for the need of pupils to start think critically and creatively as well as to discover questions and come out with possible answers, instead of resorting to multimedia. Shyamlee and Phil (as cited in Pazilah et al., 2019) also stated that integration of technologies will contribute to the lack of communication between teachers and pupils.

Besides that, pupils are also highly distracted since technology offers a lot of entertaining activities (Pazilah et al., 2019). For example, instead of seeking knowledge using the Internet, they rather find entertainment available on social medias (such as TikTok and Instagram), which explains for close supervision on pupils' activities when surfing the Internet. One reason is their exposure to unwarranted harm and danger (Pazilah et al., 2019). Another challenge as found by Lawrence et al. (2019) is the resistance to change. Most teachers prefer the use of traditional teaching method, which causes a dilemma at meeting the current ministerial demand of integrating 4IR into teaching. Teachers who are less enthusiastic and unmotivated about 4IR, are also likely to find it difficult to integrate technologies in language classrooms (Lawrence et al., 2019). They are always expected to be aware of current demands since teachers are responsible to guide and support ESL pupils to use technologies in the classroom (Razak, Alakrash \& Sahboun, 2018). In addition, Razak et al. (2018) discovered that teachers are not ready to integrate technology into their teaching practices since there are many difficulties encountered (such as the lack of tools, old infrastructure in schools and the lack of skills sand training). This further reiterates the fact that teachers are not ready to integrate technology into their teaching practices in line with the demands of $4 \mathrm{IR}$ due to not only to their insufficiency but also caused by their environment, facilities, and administrators.

Nevertheless, Hashim, Rafiq and Yunus (2019) claimed that integrating technologies into teaching practices, especially in languages is necessary in order to achieve learning outcomes. They proposed that ESL learners can improve their grammar through gamification (Hashim et al., 2019). However, Razak et al. (2018) argued that integrating technology into English classroom will not be successful if teachers are not willing to do it since they are considered as an essential component in a classroom. Teachers are not ready to integrate technologies in the teaching of English language since they encountered many challenges in moderating two things at the same time-integrating technology and the teach- 
ing of English language (Razak et al., 2018).

\subsection{The Conceptual Framework}

In line with the literature review, several initial results from previous research indicated that synthesizing information from different articles can assist the authors to develop a more scientific knowledge base. One of the vital elements in TAM3 model is experience, which moderates three relationships that were not empirically tested in Venkatesh (2000) and Venkatesh and Davis (2000). Venkatesh and Bala (2008) identified three relationships in TAM3 are 1) perceived ease of use and perceived usefulness, 2) computer anxiety and perceived ease of use, and 3) perceived ease of use and behavioural intention.

Venkatesh and Bala (2008) proposed that the influence of perceived ease of use on perceived usefulness will become stronger when ESL primary teachers' experience of using technologies is amplified because they will be able to assess their capability of obtaining high-level goals through the use of information gathered from experience. Similarly, computer anxiety on perceived ease of use of technologies will decrease as time passes when the users had more experience in using technologies. Consequently, when the users are familiar with using technologies, their behavioural intention will recede into the background and they feel it is less important to perceive ease of use as they are able to form behavioural intention when they are using technologies.

Therefore, in order to investigate the level of knowledge and readiness in integrating 4IR in their teaching practices among ESL primary school teachers, the authors proposed the use of TAM3 model as a guideline in obtaining the data needed. Based on TAM3 model, a framework was designed (as shown in Figure 3), which answers the research questions.

\section{Research Framework}

\subsection{Suggested Research Methodology}

The scope of deciding a research methodology includes choosing both the right research techniques or methods and deciding effective steps that help answer the

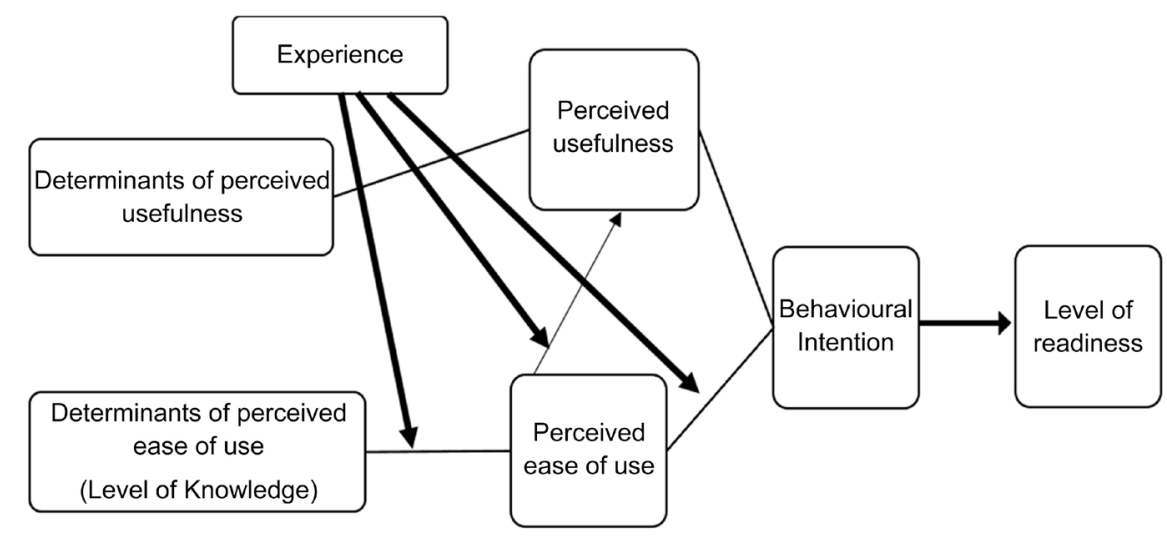

Figure 3. The conceptual framework. 
research questions (Ang, 2016). Thus, deciding a methodology is an important phase in any research, which includes the method of collecting data to obtain valid, reliable and accurate data. As such, this section discusses the choice of instruments, population, data collection method and data analysis which help answer the research questions.

Based on the proposed theoretical framework (as suggested in Figure 3), future research will be able to find out the level of knowledge and readiness of ESL primary school teachers in integrating 4IR into their teaching practices. For future research, it is proposed that data collection on the level of knowledge and readiness among ESL primary school teachers in integrating 4IR into teaching practices can be obtained by conducting quantitative method. It is highly recommended to use quantitative method since it will allow correlation. A correlation research design is a quantitative research that provides an opportunity for the research to predict scores and explain the relationship among variables (Creswell, 2012). Moreover, correlation research allows the research to conduct data collection from one specific group of people and at a determined period of time since they have no interest in the participants' history, profile or future.

\subsection{Suggested Research Analysis}

Research analysis process can be done by using logical and analytical reasoning to evaluate the data that will be collected (Perez, 2019). Thus, the authors proposed to use descriptive analysis that allow them to determine ESL teachers' level of knowledge and readiness in integrating 4IR in their teaching practices. Descriptive analysis also able to determine the overall trend of this research that will help to bridge the existing gap in the literature. Perez (2019) also claimed that the quantification of data to analyse data that will be collected able to generalize the population chosen based on result that can be derived from the sample chosen.

\subsection{Research Design \& Ethics}

As suggested by Creswell (2012), three interrelated steps are identified in the process of sampling and data collection (see Figure 4).

The first step is to specify the research population. There are two types of population to be considered in this research study, which are wider and targeted population since the focus is on educational research. In this research, every Malaysian ESL teacher makes up the wider population while selected ESL teachers in a specific group based in an identified area and level of education will form the target population.

The second step is dual-focused: to determine the research sample that appropriates the target population and to get their permission to be studied. An appropriate sample size is an indispensable part for hypothesis testing in order to obtain an accurate measurement (Welkowitz, Cohen \& Ewen, as cited in Boset et al., 2017). The authors will ensure that the chosen sampling method is 


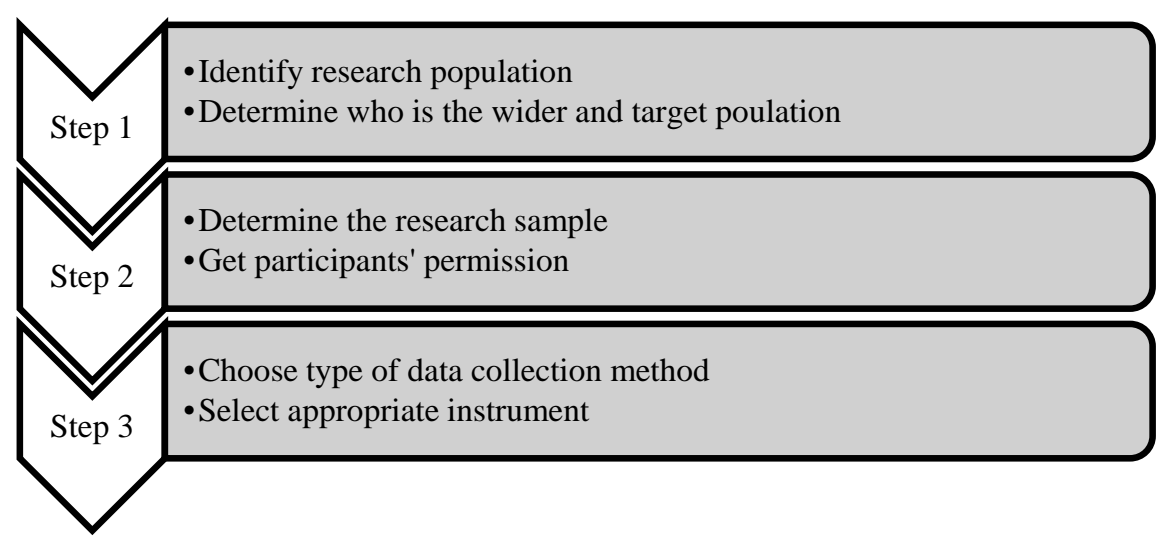

Figure 4. Process of collecting data (Creswell, 2012).

able to represent the selected population. As mentioned before, the population to be studied in this research are Malaysian ESL teachers who teach English in primary schools. In lieu of that, the authors may consider probability sampling because probability sampling enables them to make inferences about the target population as well as allow more precise measurement of the survey in terms of standard errors and confidence interval (Australian Bureau of Statistics, n.d.).

The third step is to identify the intended type of data to be collected, besides determining the instrument for data collection and collecting data. Instruments that can be administered in this research can be questionnaire, assessment instruments or tests. There are a few questionnaires that can be used for data collection purpose from the chosen participants to elaborate further based on example given. Researchers can adapt and/or adopt questionnaire that was constructed by Venkatesh and Bala (2008) that helps to gauge the level of knowledge and awareness of ESL primary school teachers in integrating 4IR into their teaching practices. Researchers may also adapt or adopt questionnaires constructed by Al-Maroof et al. (2021) that help to investigate students' acceptance of technologies since acceptance is associated to the level of readiness in integrating 4IR as part of classroom activities. All the data collected using quantitative instruments can be triangulated using qualitative instruments such observation, interviews and open-ended questions to gather more established findings.

\section{Conclusion}

Many studies have been conducted on 4IR propelling to teachers' level of knowledge, readiness and acceptance in higher level education or secondary level education. However, there are also needs for research on 4IR level of knowledge and readiness among primary school teachers to be conducted since primary school pupils are expected to be exposed to elements of 4IR. Nevertheless, Malaysianbased studies on ESL primary teachers' level of knowledge and readiness in integrating 4IR into their teaching practices are still limited. Therefore, both authors proposed the use of the suggested conceptual framework that will help to determine ESL teachers' level of knowledge and readiness in integrating 4IR in their 
teaching practices.

The following recommendation can be suggested in light of the above conceptual paper to investigate ESL primary school teachers' level of knowledge and readiness in integrating 4IR in their teaching practices. First of all, it is recommended to further investigate elements that can help to gain information on ESL primary school teachers' level of knowledge and readiness in integrating 4IR. It is also suggested to further investigate the most influential elements that affect ESL primary school teachers' level of knowledge and readiness in regard to 4IR. Lastly, it is recommended to conduct research that used TAM3 model to assess ESL primary school teachers' level of knowledge and readiness in regard to 4IR in various stages and in both public and private schools separately and the comparative studies should be done as well in this regard.

In addition, the findings of this study should be able to enlighten the stakeholders; education policymakers, teachers-educators and primary school management authorities in identifying factors that hinder teachers to learn more about 4IR as teachers need to be aware of 4IR to help their pupils to be more prepared in the future.

\section{Conflicts of Interest}

The authors declare no conflicts of interest regarding the publication of this paper.

\section{References}

Ahmadi, R. M. (2018). The Use of Technology in English Language Learning: A Literature Review. International Journal of Research in English Education, 3, 115-125. http://ijreeonline.com/article-1-120-en.html https://doi.org/10.29252/ijree.3.2.115

Al-Maroof, R. S., Alshurideh, M. T., Salloum, S. A., AlHamad, A. Q. M., \& Gaber, T. (2021). Acceptance of Google Meet during the Spread of Coronavirus by Arab University Students. Informatics, 8, 24. https://doi.org/10.3390/informatics 8020024

Anaelka, H. A. (2018). Education 4.0 Made Simple: Ideas for Teaching. International Journal of Education \& Literacy Studies, 6, 92-98. https://doi.org/10.7575/aiac.ijels.v.6n.3p.92

Ang, K. H. (2016). Pengenalan rangkakerja: Metodologi dalam kajian penyelidikan: Satu kajian literatur. Malaysian Journal of Social Sciences and Humanities, 1, 17-24.

Anon (2020). Industry 4.0: The Fourth Industrial Revolution-Guide to Industry 4.0. Sumberelektronik: I-scoop.

https://www.i-scoop.eu/industry-4-0/\#Industry 40 the essence explained in a nutshell

Aprianti, V., \& Sahid, S. (2020). The Relationship between Teachers' Competency and Fourth Industrial Revolution (4IR) Learning among Economics Teachers. Universal Journal of Educational Research, 8, 63-70. https://doi.org/10.13189/ujer.2020.082108

Australian Bureau of Statistics, Australian Government (n.d.). https://www.abs.gov.au/websitedbs/d3310114.nsf/home/Basic+Survey+Design+-+Sam ple+Design

Bahrin, M. A. K., Othman, M. F., Azli, N. H. N., \& Talib, M. F. (2016). Industry 4.0: A Review on Industrial Automation and Robotic. Jurnal Teknologi, 78, 6-13. 
https://doi.org/10.11113/jt.v78.9285

Balkaran, S. (2017). The Fourth Industrial Revolution-Its Impact on the South African Public Sector (pp. 1-21).

https://www.academia.edu/22826511/THE FOURTH INDUSTRIAL REVOLUTION ITS IMPACT ON THE SOUTH AFRICAN PUBLIC SECTOR

Boset, S. A. A., Adelina, A., \& Nabeel, A. (2017). A Conceptual Analysis of the Factors Affecting EFL Teachers' Professional Performance. International Journal of Language Education and Applied Linguistics (IJLEAL), 7, 65-75.

Butler-Adam, J. (2018). The Fourth Industrial Revolution and Education. South African Journal of Science, 114, 1. https://doi.org/10.17159/sajs.2018/a0271

Cho, H. S., \& Woo, T. H. (2017). Cyber Security in Nuclear Industry-Analytic Study from the Terror Incident in Nuclear Power Plants (NPPs). Annals of Nuclear Energy, 99, 47-53. https://doi.org/10.1016/j.anucene.2016.09.024

Creswell, J. W. (2012). Educational Research: Planning, Conducting, and Evaluating Quantitative and Qualitative Research (4th ed.). Pearson.

Erboz, G. (2017). How to Define Industry 4.0: The Main Pillars of Industry 4.0. Managerial Trends in the Development of Enterprises in Globalization Era, Nitra, 761-767. https://www.researchgate.net/publication/326557388 How To Define Industry 40 Main Pillars Of Industry 40

Gleason, N. W. (2018). Higher Education in the Era of the Fourth Industrial Revolution (p. 229). Springer Nature. http://library.oapen.org/handle/20.500.12657/23279 https://doi.org/10.1007/978-981-13-0194-0

Hashim, H., Rafiq, R. M., \& Yunus, M. (2019). Improving ESL Learners' Grammar with Gamified-Learning. Arab World English Journal (AWEJ) Special Issue on CALL, No. 5, 41-50. https://doi.org/10.24093/awej/call5.4

Haug, K. H., Kretschmer, T., \& Strobel, T. (2016). Cloud Adaptiveness within Industry Sectors-Measurement and Observations. Telecommunications Policy, 40, 291-306. https://doi.org/10.1016/j.telpol.2015.08.003

Kamaruddin, I., \& Che A. L. (2018). Pengetahuan dan kesediaan revolusi industri 4.0 dalam kalangan pelajar Institut Pendidikan Guru Kampus Ipoh. The Online Journal of Islamic Education, 6, 18-26.

Kincaid, J. P., Hamilton, R., Tarr, R. W., \& Sangani, H. (2003). Simulation in Education and Training. In Applied System Simulation (pp. 437-456). Springer.

https://doi.org/10.1007/978-1-4419-9218-5 19

Lawrence, R., Lim, F. C., \& Haslinda, A. (2019, December). Strengths and Weaknesses of Education 4.0 in the Higher Education Institution. International Journal of Innovative Technology and Exploring Engineering (IJITEE), 9, 511-519.

https://doi.org/10.35940/ijitee.B1122.1292S319

Malaysia Education Blueprint (2013). Malaysia Education Blueprint 2013-2025. Education, 27, 1-268.

Maria, M., Faaizah, S., \& Pee, N. C. (2018). Malaysian Higher Education System towards Industry 4.0-Current Trends Overview. Proceedings of the 3rd International Conference on Applied Science and Technology (ICAST'18), Penang, 10-12 April 2018, Article ID: 020081. https://doi.org/10.1063/1.5055483

Maziahtusima, I., Hazlina, A., Sakinah, A., \& Yuslina, M. (2018). Mendepani cabaran era Revolusi Industri 4.0: Hubungan amalan pembelajaran berterusan dengan prestasi peranan guru pendidikan islam sebagai agen perubahan masyarakat. Prosiding Seminar Kebangsaan Majlis Dekan Pendidikan Universiti Awam, 729-738. 
https://www.researchgate.net/publication/346261335

Ministry of Higher Education (2018). Framing Malaysian Higher Education 4.0: Future Proof Talents. Department of Higher Education Malaysia. https://adec.um.edu.my/pdf/Framing malaysian HE4.0.pdf

Mofareh, A. A. (2019). The Use of Technology in English Language Teaching. Frontiers in Education Technology, 2, 168-180. https://doi.org/10.22158/fet.v2n3p168

Mpungose, C. B. (2020). Student Teachers' Knowledge in the Era of the Fourth Industrial Revolution. Education and Information Technologies, 25, 5149-5165. https://doi.org/10.1007/s10639-020-10212-5

Nor Azizah, J., Tuan Mastura, T. S., Diyana, S. N. M., \& Zanaton, H. I. (2019). Science Teacher's Knowledge, Understanding and Readiness in Dealing with the Education Transformation of the 4th Industrial Revolution. Science Teacher, 7, 102-119. https://www.ijicc.net/images/vol7iss11/71107 Junid 2019 E R.pdf

Oke, A., \& Fernandes, F. A. (2020). Innovations in Teaching and Learning: Exploring the Perceptions of the Education Sector on the 4th Industrial Revolution (4IR). Journal of Open Innovation: Technology, Market, and Complexity, 6, 31-53. https://doi.org/10.3390/joitmc6020031

Ong, C. H., Shukor, M. F. A., Lim, L. P., Tan, O. K., \& Goh, C. F. (2019). Factors Influencing Teacher Job Satisfaction in Malaysia. International Journal of Academic Research in Business and Social Sciences, 9, 1166-1174. https://doi.org/10.6007/IJARBSS/v9-i1/5628

Pazilah, F. N., Hashim, H., \& Yunus, M. M. (2019). Using Technology in ESL Classroom: Highlights and Challenges. Creative Education, 10, 3205-3212. https://doi.org/10.4236/ce.2019.1012244

Perez. E. (2019). What Is Data Analysis and Its Methods. Utree. https://www.utreee.com/what-is-data-analysis-and-its-methods\%EF\%BB\%BF

Quarles, A. M., Conway, C. S., Harris, S. M., Osler, J. E., \& Rech, L. (2018). Integrating Digital/Mobile Learning Strategies with Students in the Classroom at the Historical Black College/University (HBCU). In J. Keengwe (Ed.), Handbook of Research on Digital Content, Mobile Learning, and Technology Integration Models in Teacher Education (pp. 390-408). IGI Global. https://doi.org/10.4018/978-1-5225-2953-8.ch020

Rafiq, K. M., Hashim, H., Yunus, M. M., \& Norman, H. (2020). iSPEAK: Using Mobile-Based Online Learning Course to Learn "English for the Workplace".

Razak, N. A., Alakrash, H., \& Sahboun, Y. (2018). English Language Teachers' Readiness for the Application of Technology towards Fourth Industrial Revolution Demands. Asia-Pacific Journal of Information Technology and Multimedia, 7, 89-98.

https://www.researchgate.net/publication/346906587

https://doi.org/10.17576/apjitm-2018-0702(02)-08

Romy. A. K., Mohd Asri, A. A., Mohd Khalid, H., Normah, A. R., \& Mohd Ali, S. (2020). Tahap pengetahuan dan tahap kesediaan guru pelatih Institut Pendidikan Guru Kampus Pendidikan Teknik (IPGKPT) terhadap Revolusi Industri 4.0 (IR 4.0). Jurnal Penyelidikan Teknokrat II, (JILID XXI).

http://myjms.mohe.gov.my/index.php/jpt/article/view/8400

Rüßmann, M., Lorenz, M., Gerbert, P., Waldner, M., Justus, J., Engel, P., \& Harnisch, M. (2015). Industry 4.0: The Future of Productivity and Growth in Manufacturing Industries. Boston Consulting Group, 9, 54-89.

https://inovasyon.org/images/Haberler/bcgperspectives Industry40 2015.pdf

Schafer, M. (2018). The Fourth Industrial Revolution: How the EU Can Lead It. European View, 17, 5-12. https://doi.org/10.1177/1781685818762890 
Schwab, K. (2016). The Fourth Industrial Revolution: What It Means and How It Responds. Currency Books.

Subekt, H., Taufiq, M., Susilo, H., Ibrohim, I., \& Suwono, H. (2017). Mengembangkan literasi informasi melalui belajar berbasis kehidupan terintegrasi stem untuk menyiapkan calon guru sains dalam menghadapi era Revolusi Industri 4.0: Revieu Literatur. Education and Human Development Journal, 3, 81-90. https://doi.org/10.33086/ehdj.v3i1.90

Sulaiman, T., Hamzah, S. N., \& Rahim, S. S. A. (2017). The Relationship between Readiness and Teachers' Competency towards Creativity in Teaching among Trainee Teachers. International Journal of Social Science and Humanity, 7, 10-13. http://www.ijssh.org/vol7/883-SH057.pdf

Van, L. K., Dang, T. A., Pham, D. B. T., Vo, T. T. N., \& Pham, V. P. H. (2021). The Effectiveness of Using Technology in Learning English. AsiaCALL Online Journal, 12, 24-40. https://asiacall.info/acoj/index.php/journal/article/view/26

Venkatesh, V. (2000). Determinants of Perceived Ease of Use: Integrating Perceived Behavioral Control, Computer Anxiety and Enjoyment into the Technology Acceptance Model. Information Systems Research, 11, 342-365. https://doi.org/10.1287/isre.11.4.342.11872

Venkatesh, V., \& Bala, H. (2008). Technology Acceptance Model 3 and a Research Agenda on Interventions. Decision Sciences, 39, 273-315. https://doi.org/10.1111/j.1540-5915.2008.00192.x

Venkatesh, V., \& Davis, F. D. (2000). A Theoretical Extension of the Technology Acceptance Model: Four Longitudinal Field Studies. Management Science, 46, 186-204. https://doi.org/10.1287/mnsc.46.2.186.11926

Xu, M., David, J. M., \& Kim, S. H. (2018). The Fourth Industrial Revolution: Opportunities and Challenges. International Journal of Financial Research, 9, 90-95. https://doi.org/10.5430/ijfr.v9n2p90

Yunus, M. M. (2018). Innovation in Education and Language Learning in 21st Century. Journal of Sustainable Development Education and Research, 2, 33-34. https://doi.org/10.17509/jsder.v2i1.12355 